\title{
The provision of recreation services for the aged in the Durban Metropolitan Area (DMA)
}

\author{
NR Ngcobo' \\ Department of Recreation and Tourism, University of Zululand, South Africa \\ rngcobo@pan.uzulu.ac.za
}

\begin{abstract}
This paper investigated the provision of recreation services for the aged in the Durban Metropolitan Area (DMA). The main argument in the research is that the aged like any other age groups need to be provided with recreation services. The objectives underpinning this investigation include the following:

- To reveal the adequacy of existing recreation services which are provided for the aged in the Durban Metropolitan Area.

- To determine the views that the aged population holds towards recreation participation by the aged.

- To establish the extent to which the aged in the Durban Metropolitan Area value their recreation participation.

- To establish the level of concessions granted to the aged by the recreation service providers in the Durban Metropolitan Area on utilising recreation facilities.

A survey research method, comprising a self-completed questionnaire and a structured interview schedule, was used to gather data from the respondents who comprised 260 aged (main sample), 120 general members of the public and 10 recreation service providers in the DMA. This was further supplemented by the observation method. Having analysed the data, the chi-square test was used to test the validity and reliability of the hypotheses.

The most salient findings indicate that the aged in the DMA are not adequately provided with recreation services, despite the fact that they attach certain positive values to recreation participation. The research further highlighted that the DMA needs to provide recreation programmes that the aged can afford.

Non-prescriptive recommendations revolve inter alia around: conducting a needs analysis survey prior to the provision of recreation services for the aged. The location of recreation facilities to be used by the aged must be in an area that is easily accessible. Furthermore, the aged must be granted special concessions in the utilisation of recreation facilities.
\end{abstract}

Keywords: Aged person, recreation services, Durban, Durban Metropolitan Area, South Africa

\section{Introduction}

This paper focuses on the provision of recreation services for the aged in the Durban Metropolitan Area (DMA). Its foundation among others is the premise that "The joy that comes from engaged in recreation activities should be experienced by everyone" (Weiskopf (1982: 2I). Thus, for people to be involved in recreation activities, irrespective of the age structure under which they fall, recreation facilities, services and opportunities need to be made available. Recreation participation is reward laden for almost all age groups. Carlson et al. (1979) list the recreation participation rewards as the following: physical well being; emotional health; the quest for identity, commitment, or 'a piece of action'; sense of community; learning; self image, self-esteem, and self-fulfilment; personality development; social interaction and social integration; adventure, and the opportunity to find an acceptable balance

This author observes that the majority of the aged population, especially those who come from the previously disadvantaged communities, partially neglect using their leisure time by participating in recreation activities. We do assume that this partial neglect of recreation participation by the aged population has something to do with lack of retirement preparation programmes, the inadequate provision of relevant recreation services, as well as the absence of relevant recreation programmes. It may well be that recreation needs/ demands of the aged population are not well catered for by the providers of recreation opportunities.

This paper has been undertaken to answer the following questions about the aged in the Durban Metropolitan Area:

a Are the aged in the Durban Metropolitan Area adequately provided with recreation services?

b To what extent are the recreation demands or needs of the aged in the Durban Metropolitan Area met? and

c What is the local government policy towards providing recreation services in the Durban Metropolitan Area?

It is hypothesised that:

The aged population in the Durban Metropolitan Area is not adequately provided with recreation and tourism facilities.

a There is a lack of need analysis when it comes to the provision of recreation and tourism facilities for the aged population in the Durban Metropolitan area.

I. NR. Ngcobo,PhD, is a Senior Lecturer in the Department of Recreation and Tourism and the University of Zululand, South Africa.

Inkanyiso, Jnl Hum \& Soc Sci 20I I, 2(2) 
b Recreation participation by the aged living in the Durban Metropolitan Area can improve if relevant recreation programmes can be conducted.

c Participation of the Durban Metropolitan Area's aged populace in recreation activities benefits them physically, emotionally, socially and educationally.

d The aged in the Durban Metropolitan Area who are participating in recreation activities value their participation.

e The aged prefer a recreation facility to be easily accessible.

$f$ The aged must be granted a special concession by the recreation services providers for making use of the latter's recreation services.

\section{Theoretical framework}

Before highlighting the theory informing this study, the concepts recreation, leisure, recreation services, metropolitan city and the aged as used in this article require clarification. Recreation is understood to be an activity or experience carried out within leisure time, usually chosen by the participant, either because of the satisfaction, pleasure or creative enrichment derived, or because he or she perceives certain personal or social values to be gained from them (Edginton et al. 1995; Torkildsen 200I; Magi 1988 and Bucher 1983). Leisure is a term that has brought innumerable debates among authors writing about this field. Like recreation, leisure has failed to achieve a universally accepted definition. According to Edginton et al. (1995), leisure means different things to different people. In the context of this paper, an explanation by Murphy (198I) has been adopted. The concept leisure according to Murphy (198I) is categorised into time, function, spatial environment and an integrative-synthesising perspective, holism. What is striking in Murphy's (198I) categorisation of leisure is that leisure is not defined as an activity but rather includes time, and attitudes toward time and non-work activities. Leisure, therefore, throughout the paper is treated as free time related, that is, time at the disposal of the individual, which the individual can spend as he or she choose. Recreation services take into consideration the available recreation facilities, offered recreation programmes, and participation in recreation activities. In essence the term recreation services encapsulates all recreation opportunities that are accompanied by recreation facilities, recreation programmes and recreation activities. Consequently, the use of the term recreation services is limited to recreation facilities, recreation programmes and recreation activities. The term recreation facility can be limited to recreation resources. According to Eckstein and Noah (1973), a metropolitan area is a special form of the urban environment, whose influence is great and extends beyond its boundaries. The influence and the importance of a metropolitan area are clearly recognised in commerce, communications and politics.

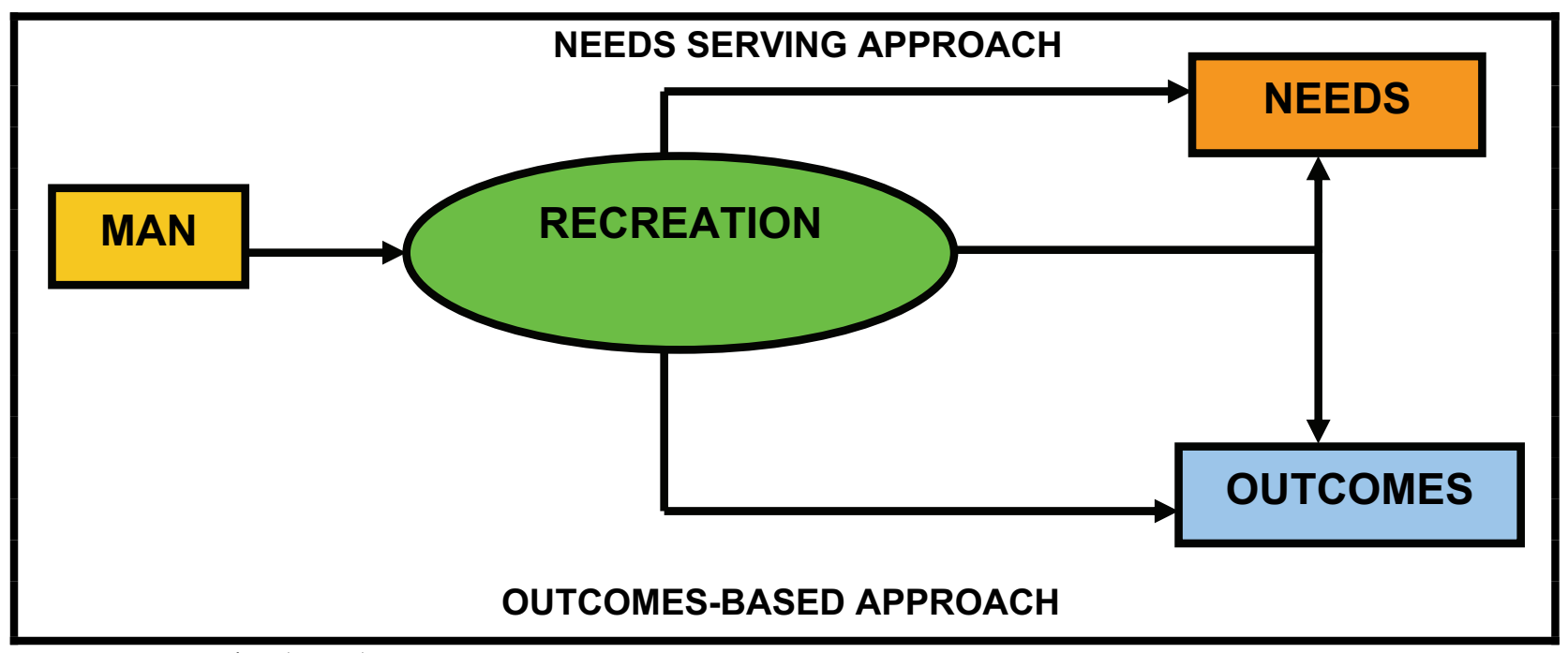

Source: Ngcobo (1998)

Figure 1 Approaches in recreation

A metropolitan area is characterised by social and economic heterogeneity, high levels of population mobility, and a disproportionate concentration of skilled manpower and economic activities of particular types. The term aged specifically refers to people who have already retired from work. In South Africa, initially females could retire when they 
reach the age of fifty-five and males when they reach the age of sixty. As a result of Act 108 of 1996 section 9 (3) that states that people may not be unfairly discriminated on the basis of race, gender, sex, pregnancy, marital status, ethnic or social origin, colour, sexual orientation, age, disability, religion, conscience, belief, culture, language and birth, males who have reached the age of fifty-five can also retire from work, hence the age of fifty-five has been considered as a stage reached by people who are the aged.

The general theory that has been postulated by different authors including Oldman (1996): South African White Paper (1998); Ngcobo (1998); Kraus (200I); Torkildsen (200I); Edginton et al. (1995); Marsland (1987); Rodgers (1985); Smith and Theberge (1987); Weiskopf (1982); Voskanyan et al. (2003) to mention only a few, states that human beings involve themselves in recreation because there are certain natural needs that must be fulfilled (Needs Serving Approach) and that human beings recreate because of certain benefits that are derived from recreation (Outcomes Based Approach). These needs are graphically illustrated in Figure I above.

In the Needs Serving Approach (NSA) the above figure emphasises the fact that some people engage themselves in recreation because recreation participation fulfills certain needs in them. Self actualisation, esteem, love and belonging, safety and physiological development are some of those needs. An Outcomes Based Approach (OBA) on the other hand focuses on the benefits that are accrued through recreation. The well documented benefits that encourage people to participate in recreation are related to health improvement, social and personal development.

\section{Research methodology}

As this research was examining the provision of recreation services for the aged in the Durban Metropolitan Area the policies related to the provision and management of recreation facilities, services, opportunities and activities within the study area, the collection of data were therefore limited to the aged.

Four data collection strategies or methods have been employed. These are questionnaires, interviews, observations and secondary data. The four strategies have been preferred because of the nature of the research problem and the kind of information desired by the researcher. The nature of the research problem demanded respondents to come from different cultural backgrounds and that representation must come from different local councils in the Durban Metropolitan Area.

Before distributing the questionnaires, more especially the main questionnaire to the main population sample, a pilot study, or a pre-test was conducted. Three sets of questionnaires were distributed to the aged population in the study area (the main population sample), the general public, and the service providers. Owing to the fact that the main population sample might experience language constraints, a decision was made to provide the questionnaires in both English and Zulu. Most of the questions in the questionnaire were closed-ended questions. There were about 500 questionnaires that were distributed. The response rate was fifty two percent $(65 \%)$, which is equal to 260 respondents.

Interviews focused on service providers. There were ten (10) randomly selected service providers interviewed. The face-to-face interviews were guided by structured interview schedules for consistency purposes. The reason for conducting face-to-face interviews with the recreation service providers is that most of them wanted to know the aim behind conducting the research, as well as how research of this nature would benefit them, as they had the feeling that the aged population is a neglected sector when it comes to recreation services. Interviews would also provide better clarification and give a better understanding about the issues that are revealed by the questionnaire and also support reliability by triangulation of results obtained through other data collection methods.

Non-participant observation was used. The use of the non-participant observation was preferred over the other types for the reason that one can find the main sample population in their natural form. The non-participant observation has been used in order to confirm whether the aged population do participate in some of the recreation activities designed for them by the recreation service providers. The local councils that the researcher visited with an aim of determining the participation of the aged group in recreation activities included the inner west, south central, and north central. These areas were visited because their aged organisations indicated that they host days for the aged day. It was observed that the aged are interested in organised recreation activities but they do not attend these activities in their numbers.

The total research sample of the study was 260. This figure was arrived at by making use of Magi's (1998) Table of Estimation of Sample Size from a Given Population, where he suggested that the sample need to be within \pm 0.05 of the population proportion, $\mathrm{P}$, with a $95 \%$ level of confidence. In this study therefore the population at the time when the study was conducted was in the region of 300000 .

Table I shows the number of the distributed questionnaires to the main research sample and the number of questionnaires that were returned.

Inkanyiso, Jnl Hum \& Soc Sci 20I I, 2(2) 
Table I distribution of questionnaires (actual frequencies)

\begin{tabular}{lllll}
\hline \multicolumn{1}{c}{ LOCAL COUNCILS } & DISTRIBUTED QUESTIONNAIRES & \multicolumn{2}{c}{ RETURNED QUESTIONNAIRES } \\
\cline { 2 - 5 } Nrequency & Percentage & Frequency & Percentage \\
North Council & 040 & 08 & 024 & 09.23 \\
North Central Council & 145 & 29 & 076 & 29.23 \\
Outer west Council & 030 & 06 & 016 & 06.15 \\
Inner west Council & 065 & 13 & 033 & 12.70 \\
South central Council & 195 & 39 & 100 & 38.46 \\
South Council & $\mathbf{0 2 5}$ & 05 & 011 & 04.23 \\
Total & $\mathbf{5 0 0}$ & $\mathbf{1 0 0}$ & $\mathbf{2 6 0}$ & $\mathbf{1 0 0}$ \\
\hline
\end{tabular}

From Table $I$ it is clear that the number of questionnaires distributed varied from one local council to another. The determining factor for this unequal distribution has been the concentration of the population. As one moves from the urban areas towards the rural areas the number of people starts to drop in terms of concentration. The trend in the Durban Metropolitan Area is that the North and the South Central Local Councils have more people than the other local councils because these two local councils also incorporate the city of Durban.

The research sample did not only limit itself to the aged as the main population sample. In addition, the general members of the public and the recreation service providers for the aged (organisations and associations) were also included. The researcher randomly selected one hundred and twenty (120) members of the public and ten (10) recreation service providers for the aged. In determining the recreation participation of the aged the study also argues the question of recreation demand (consumers) and recreation supply (agencies) in the Durban Metropolitan Area.

\section{Results}

The results are summarised in section 4.I. to 4.4 and Tables 2 to 9 together with Figures 2 to 8 .

4.1 Socio-economic demography of the respondents

In this section the respondent were required to give information on their socio-economic demography.

Table 2 Socio-economic demography of the respondents (aged) $-(N=260)$

\begin{tabular}{|c|c|c|c|}
\hline VARIABLE & SUB-VARIABLE & FREQUENCY & $\%$ \\
\hline \multirow[t]{2}{*}{ Gender } & Male & 095 & 36.5 \\
\hline & Female & 165 & 63.5 \\
\hline \multirow[t]{2}{*}{ Total } & & 260 & 100 \\
\hline & $55 y r s-64$ yrs & 096 & 37.0 \\
\hline \multirow[t]{2}{*}{ Age } & $65 y \mathrm{ys}-74 \mathrm{yrs}$ & 106 & 40.7 \\
\hline & $75 y r s$ and above & 058 & 22.3 \\
\hline \multirow[t]{3}{*}{ Total } & & 260 & 100 \\
\hline & Did not attend school & 019 & 07.3 \\
\hline & Junior Phase Level & 017 & 06.5 \\
\hline \multirow[t]{4}{*}{ Education Level } & Intermediate Phase Level & 053 & 20.4 \\
\hline & Senior Phase Level & 068 & 26.2 \\
\hline & FET-Level & 071 & 27.3 \\
\hline & Post Matriculation Level & 032 & 12.3 \\
\hline \multirow[t]{3}{*}{ Total } & & 260 & 100 \\
\hline & Single & 029 & 11.2 \\
\hline & Married & 099 & 38.1 \\
\hline \multirow[t]{3}{*}{ Marital Status } & Divorced & 029 & 11.2 \\
\hline & Widower & 030 & 11.5 \\
\hline & Widow & 073 & 28.1 \\
\hline \multirow[t]{2}{*}{ Total } & & 260 & 100 \\
\hline & Working & 024 & 09.2 \\
\hline \multirow[t]{2}{*}{ Occupational Status } & Not Working & 077 & 29.6 \\
\hline & Retired & 159 & 61.2 \\
\hline Total & & 260 & 100 \\
\hline
\end{tabular}




\begin{tabular}{llll}
\hline \multirow{3}{*}{ Source of Income } & Salary & 023 & 08.8 \\
& Pension & 182 & 70.0 \\
& Retirement Annuity & 044 & 16.9 \\
& Other & 011 & 04.2 \\
\hline Total & & $\mathbf{2 6 0}$ & $\mathbf{2 6 0}$ \\
\hline \multirow{5}{*}{ Income per Month } & Less than R400-00 & 015 & 05.8 \\
& R400-00-R799-00 & 160 & 61.5 \\
& R800-00-RI 199-00 & 030 & 11.5 \\
\hline Total & RI 200-00 - RI 599-00 & 025 & 09.6 \\
\hline
\end{tabular}

The variables that were considered include gender, age, educational level, marital status, occupational status, source of income and income per month. The broad outcomes of the collected and analysed data are depicted in Table 2 above.

Furthermore, the respondents have been requested to indicate in their questionnaires the local council in which their residences are found. This has been done with a view of establishing whether all the local councils that fall under the Durban Metropolitan Area have been represented or not. Consequently, Table 3 gives a broad overview of the number of respondents who represented each metropolitan local council.

Table 3 Respondents' place of residence in terms of local councils

\begin{tabular}{lcc}
\hline LOCAL COUNCIL & FREQUENCY & PERCENTAGE \\
\hline South Central Council & 100 & 38.46 \\
Inner West Council & 033 & 12.70 \\
North Council & 024 & 09.23 \\
Outer West Council & 016 & 06.15 \\
South Council & 011 & 04.23 \\
North Central Council & 076 & 29.23 \\
\hline TOTAL & $\mathbf{2 6 0}$ & $\mathbf{1 0 0}$ \\
\hline
\end{tabular}

From Table 3 it can be inferred that 67.69 percent of the aged population are concentrated in both the North and South Central Local Councils. This may be due to the fact that the North and South Central Local Councils include the city centre of Durban where the majority of the old age homes are found. In addition, both the North and the South Central Local Councils incorporate many townships which are known for their large concentration of people.

\subsection{Recreation and leisure interpretations}

The respondents were asked to furnish their meanings to the key concepts that underlie this study, that is, leisure and recreation. Tables 4 and 5 below what meanings the respondents attach to the concepts leisure and recreation.

About $40,8 \%$ of the respondents understand leisure as time when one is not working but doing something other than work. At the same time $25 \%$ of the respondents perceive leisure as that portion of time in which they involve themselves in recreation activities.

Table 4 Understanding of the concept of leisure

\begin{tabular}{llll}
\hline CONCEPT & CONCEPT MEANING & FREQUENCY & $\%$ \\
\hline & Time when you are not working. & 106 & 40.8 \\
& Time when you are free from work and doing nothing. & 027 & 10.4 \\
Leisure & Time when you do not know what to do. & 024 & 9.2 \\
& Time when you free from daily obligations. & 038 & 14.6 \\
& Time when you are involved in recreation activities. & 065 & 25.0 \\
\hline & TOTAL & 260 & 100 \\
\hline
\end{tabular}

This interpretation of leisure was in line with that propounded by Murphy (198I), Nakhooda (196I) and Carpenter (2003), in that leisure is that part of the individual's daily life in which he or she finds himself free from the demands of his Inkanyiso, Jnl Hum \& Soc Sci 20I I, 2(2) 
regular calling and able to enter upon any line of activity he may choose within his own interests whether it be work or play or meditation.

Table 5 Understanding of the concept of recreation.

\begin{tabular}{llll}
\hline CONCEPT & MEANING & FREQ. & $\%$ \\
\hline & Making yourself happy and enjoying your leisure time & 100 & 38,5 \\
& Entertaining yourself at your own determined pace & 30 & 11,5 \\
& Involving yourself in sports, games and play & 25 & 9,6 \\
& Engaging in activities from which you can derive pleasure and personal & 45 & 17,3 \\
Recreation & worth & 31 & 11,9 \\
& Involving yourself in any activity during your leisure time & 3 & 3,6 \\
& Refreshing yourself & 9 & 3,8 \\
& Enjoying yourself during leisure time & 10 & 3,8 \\
& Being with yourself during your leisure time & 10 & $\mathbf{1 0 0}$ \\
\hline
\end{tabular}

It is interesting to note from Table 5 above that about $58 \%$ of the respondents associate recreation with activities that take place during leisure time. In addition, $38,5 \%$ of the respondents indicate that the activities should make them happy and be enjoyable.

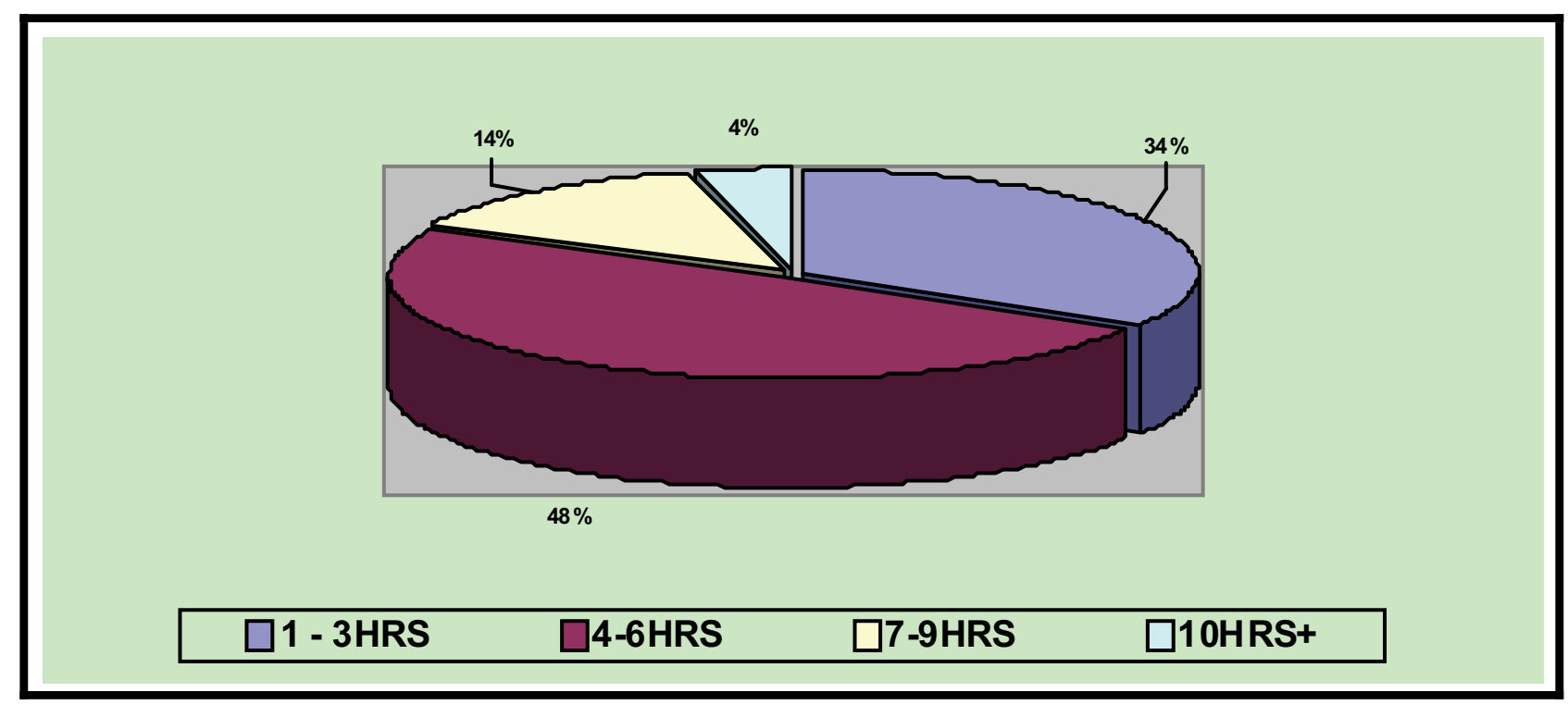

Figure 2 Leisure time available among the aged

The intention of the study in Figure 2 below was to establish the amount of time that the aged in the study area had at their disposal. About $94.2 \%$ of the respondents indicated that they do have leisure time at their disposal. What can be inferred from Figure 2 is that the majority of the respondents, $82 \%$, have leisure time that ranges from one hour to six hours per day. Only $18 \%$ of the respondents were recorded as having more than seven hours per day as their leisure time. These respondents indicated that they have leisure time that ranges from seven hours to 10 hours.

\subsection{Recreation participation of the aged}

In order to determine whether the aged in the Durban Metropolitan Area are provided with adequate recreation services or not, and if so, whether they engage in recreation activities, the study started by investigating the recreation activities in which the aged are engaged. 
Figures 3 and 4 below depict the active and passive recreation activities in which the aged in the Durban Metropolitan Area involve themselves respectively. A distinction of this nature is necessary in order to determine whether the facilities can be said to be in surplus or under-provided. Such a distinction can also help the providers in determining the facilities that are provided but under-utilised by the aged. In this case the providers can decide whether relevant programmes accompanying the provision of a recreation facility are needed or not.

In Figure 3 below it is noticeable that the majority of the respondents (more than 44\%) engage themselves in green bowling. Green bowling, is well known in many circles of life as the sport of the aged, also known colloquially among African urban communities as (Umdlalo womagrizza) 'the grand-parents' sport' or (umdlalo wamakhehla) 'the sport of the old men'. Although in recent times some aged people have been found to engage themselves in casino gaming or gambling as a form of recreation, this study established that less than $4.3 \%$ of the aged in the study area participates or regard gambling as a form of recreation. The participation of the few elderly people in gambling as a form of recreation has been affirmed by Harahousou and Kabitsis (2002), in that few elderly people involve themselves in money making activities such as gambling as a form of recreation.

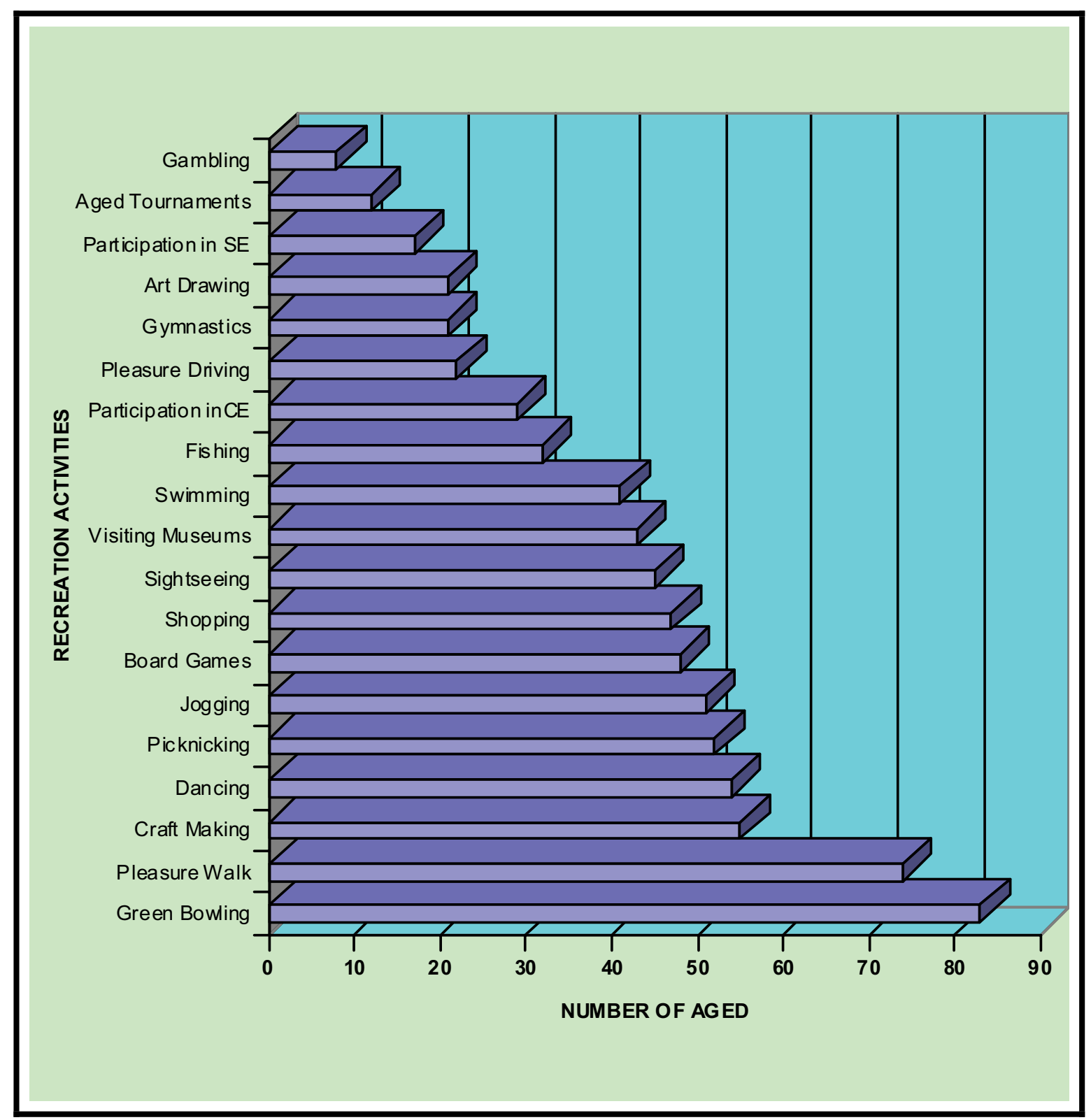

Figure 3 Active recreation activities for the aged. 
The study also revealed that about $39.7 \%$ of the aged engage in pleasure walks (taking a walk) and $29.5 \%$ of the respondents use jogging as a recreation activity. The increase in the number of aged that involve themselves in physical related recreation activities is also likely to be caused by the fact that some medical doctors, encourage the aged to participate in physical related exercises. This is affirmed by Kraus (200I) in that some medical experts have testified to the proven benefits of regular exercise that results in better health, stronger muscles, greater endurance and a general feeling of well-being and energy that the aged population needs at this stage of life.

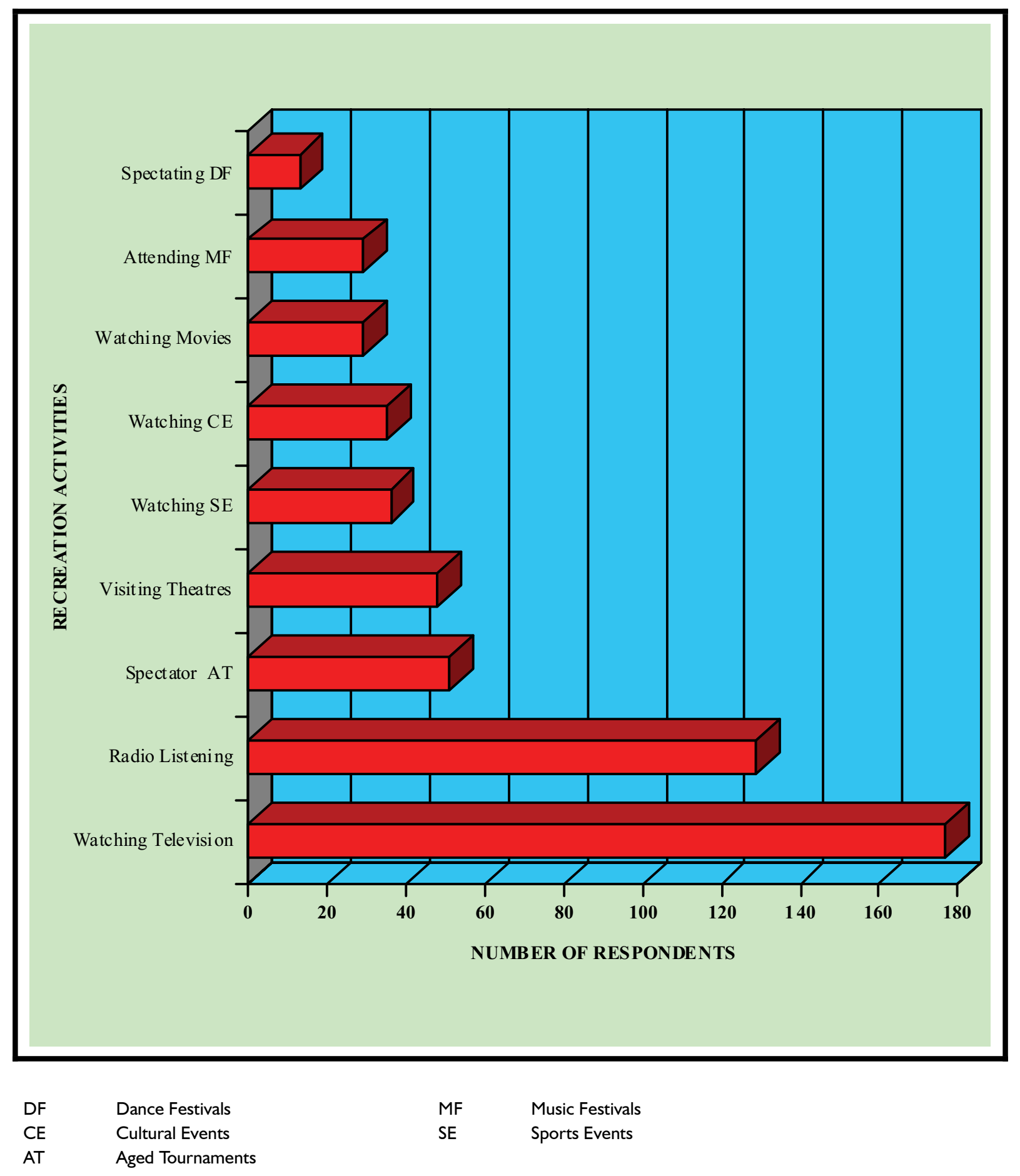

Figure 4 Passive recreation activities for the aged (frequency). 
In an attempt to establish the response of the aged to passive recreation activities, some of the related findings are indicated in Figure 4 above. From the analysis it seems that passive activities appeal more to the aged than active recreation activities. On ranking these passive activities, and understanding that each respondent selected more than one passive recreation activity, it emerged from Figure 4 above that watching television $(247 f=95.1 \%)$ and radio listening (I29 $f=49.6 \%$ ) were the most preferred activities. The moderately preferred passive activities included watching spectator tournaments, watching cultural events, watching sports events and going to the movies. The least preferred passive activities were attending dance festivals $(13 f=6.9 \%)$ and music festivals $(29 f=11.1 \%)$.

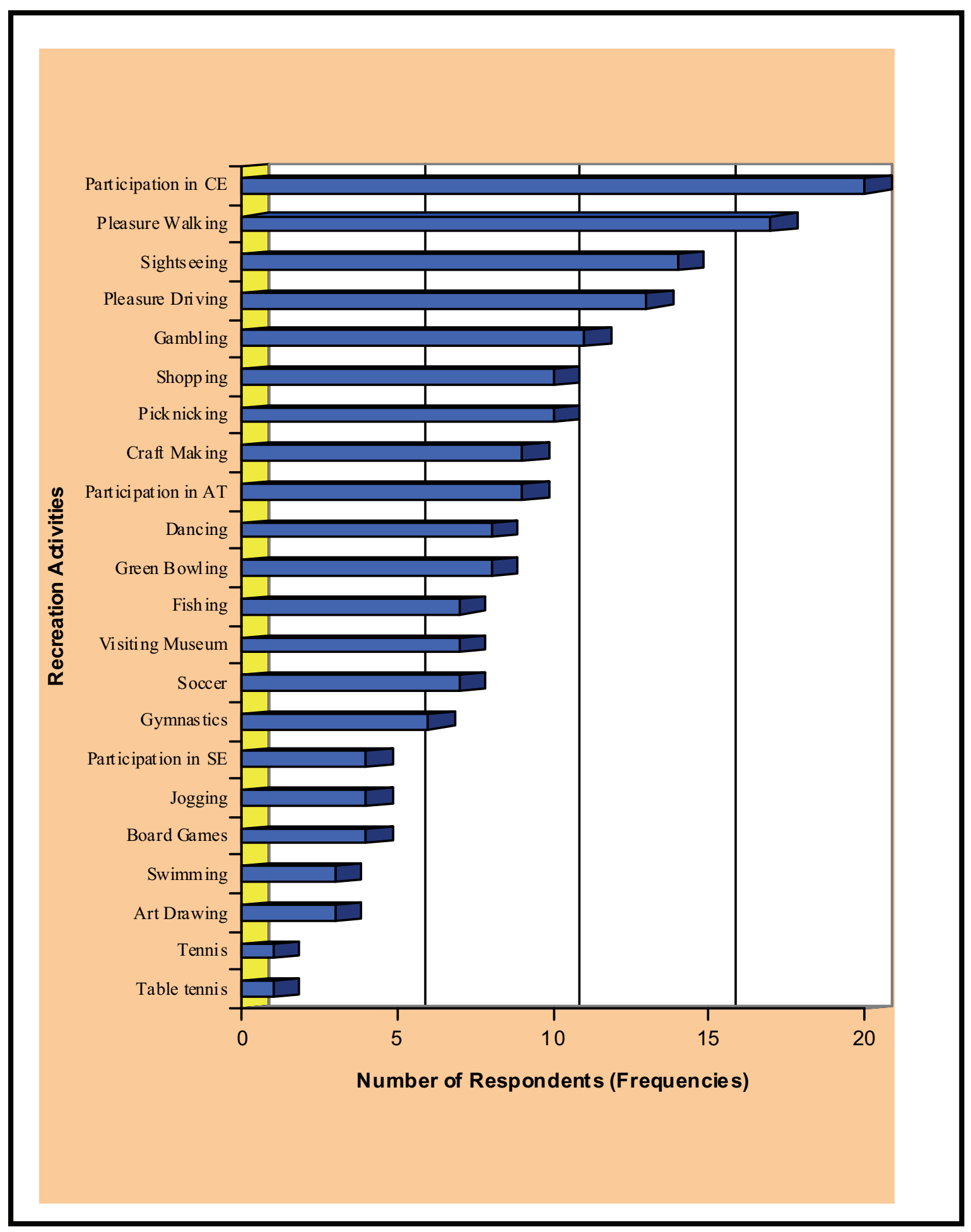

Figure 5 Preferred active recreation activities 
The respondents (aged) were further requested to indicate the types of active recreation activities in which they would prefer to participate. What can be deduced from Figure 5 is that about 27.percent of the respondents, that is, the majority prefer to participate in cultural events. Other active recreation activities that are in the first five are pleasure walking (22.9\%); sightseeing (18.9\%); pleasure driving (17.5\%); and gambling (I4.8\%). When it comes to the bottom of the graph the recreation activities are table tennis (I.3\%); tennis (I.3\%); art drawing (4.1\%); swimming (5.4\%); and board games (5.4\%). Carlson et al. (1979) in support of the cultural events topping the lists state that participation in cultural events among older persons is regarded as a service activity. They further state that the older person wants to be needed. Service to others is a viable recreation outlet in which both the server and those who are served can reap benefits.

In contrast to the preferred active recreation activities discussed above, Figure 6 below depicts the perceived preference of passive recreation activities by the non-active participants (aged).

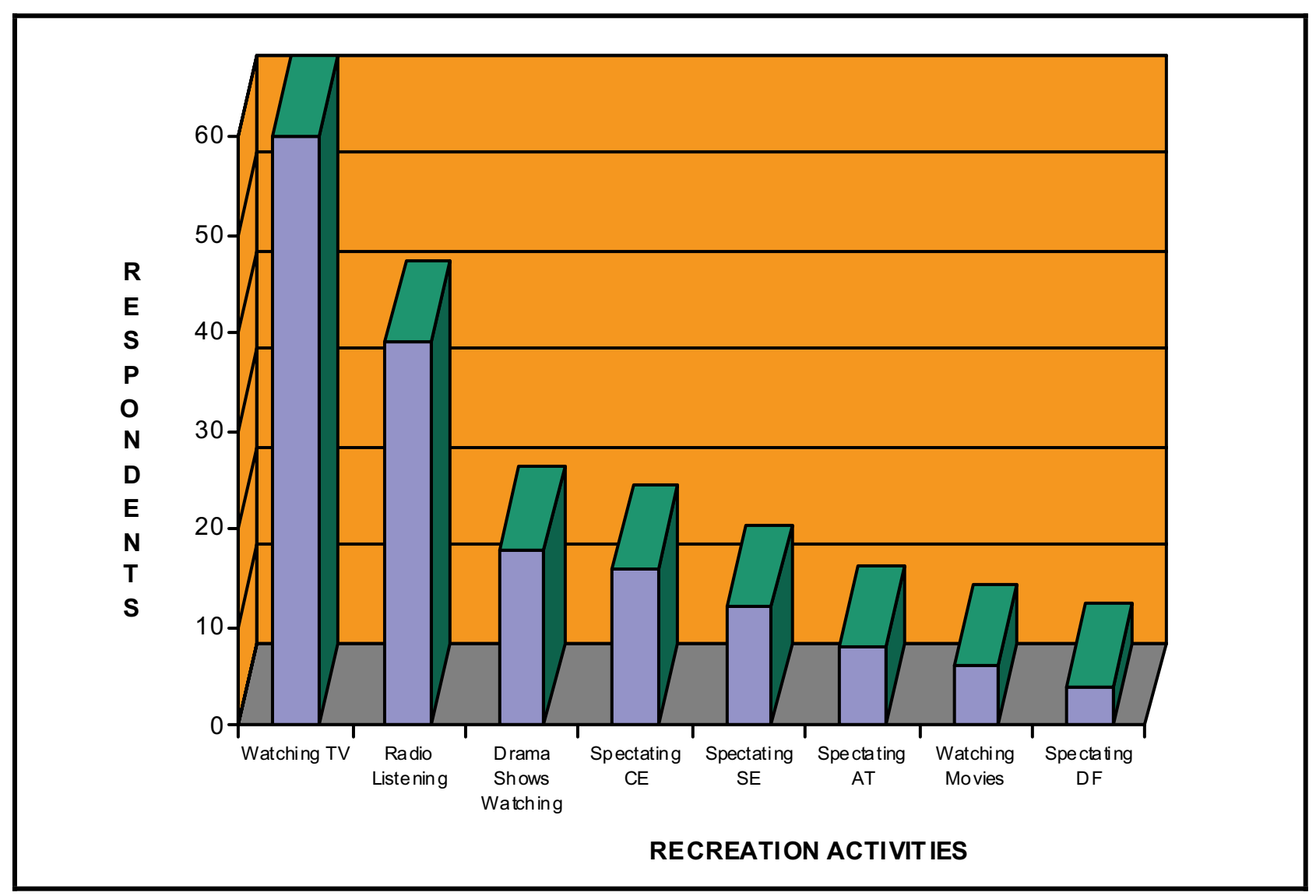

Figure 6 Preferred passive recreation activities [frequency]

About $95.1 \%$ (57 f) prefer watching television, followed by $65 \%$ (39 f) who prefer radio listening. Very similar to the active participants, the non-active participants' moderately preferred passive activities include watching spectator tournaments (AT), watching cultural events (CE), watching sports events (SE) and drama shows watching.

\subsection{Attitude of the aged to wards recreation}

The study further went on to solicit information regarding the attitudes of the aged towards the following:

- Provision of recreation facilities for the aged in the Durban Metropolitan Area;

- Recreation facilities and activities' needs analysis survey;

- Location of recreation facilities;

- Benefits of recreation participation to the aged;

- Provision of recreation programmes for the aged; and

- Provision of special concessions to participants

The attitudes of the aged towards recreation are summarised below. 


\subsection{Provision of recreation facilities for the aged in the Durban Metropolitan Area}

About $19,6 \%$ of the respondents think that the recreation facilities for the aged are fairly sufficient or adequate as against $\mathbf{8 0 . 4} \%$ that thinks that the facilities are inadequate or not available at all. Furthermore the local council perceived as having the most recreation facilities is the Durban City area.

Table 6 Opinions on available recreation facilities per local council (aged)

\begin{tabular}{|c|c|c|c|c|c|c|c|c|c|c|}
\hline \multirow{3}{*}{$\begin{array}{l}\text { DMA } \\
\text { LOCAL COUNCILS }\end{array}$} & \multicolumn{8}{|c|}{ RESPONSES } & \multirow{2}{*}{\multicolumn{2}{|c|}{ TOTAL }} \\
\hline & \multicolumn{2}{|c|}{ Many } & \multicolumn{2}{|c|}{ Sufficient. } & \multicolumn{2}{|c|}{ Few. } & \multicolumn{2}{|c|}{ Not There. } & & \\
\hline & $\mathbf{F}$ & $\%$ & $\mathbf{F}$ & $\%$ & $\mathbf{F}$ & $\%$ & $\mathbf{F}$ & $\%$ & $\mathbf{F}$ & $\%$ \\
\hline North & 06 & 25,0 & 07 & 29,2 & 08 & 33,3 & 03 & 12,5 & 24 & 100 \\
\hline North Central & 00 & 00 & 00 & 00 & 01 & 33,3 & 02 & 66,7 & 03 & 100 \\
\hline Outer West & 00 & 00 & 03 & 21,4 & 08 & 57,2 & 03 & 21,4 & 14 & 100 \\
\hline Inner West & 02 & 06,1 & 02 & 06,1 & 20 & 60,6 & 09 & 27,2 & 33 & 100 \\
\hline South Central & 04 & $05, I$ & 03 & 03,9 & 45 & 57,7 & 26 & 33,3 & 78 & 100 \\
\hline South & 01 & 12,5 & 01 & 12,5 & 05 & 62,5 & 01 & 12,5 & 08 & 100 \\
\hline Durban City & 04 & 04.0 & 18 & 18,0 & 59 & 59,0 & 19 & 19,0 & 100 & 100 \\
\hline TOTAL & 17 & 06.5 & 34 & 13,1 & 146 & 56,2 & 63 & 24,2 & 260 & 100 \\
\hline
\end{tabular}

The local councils that are not in close proximity to the city centre and are predominantly occupied by the historically disadvantaged communities are seen by the respondents to be inadequately provided with recreation facilities for its aged population. Hence 8.5 percent and less of the respondents think that they have the most recreation facilities for its aged population. This apparent way of thinking seems to be addressing the first hypothesis, that reads:

The aged population in the Durban Metropolitan is not adequately provided with recreation facilities.

\subsubsection{Recreation facilities and activities' needs analysis survey}

The respondents were asked whether they would prefer a needs analysis survey to be conducted in their area prior to the provision of recreation services. The question of a needs analysis survey in this study was an attempt to address the hypothesis that reads:

There is a lack of a needs analysis when it comes to the provision of recreation facilities for the aged population in the Durban Metropolitan Area.

More than $90 \%$ of the respondents feel that there is a lack of needs analysis survey when it comes to the provision of recreation services for the aged population in the Durban Metropolitan Area. Only less than 10\% indicated that there is no lack of a needs analysis. Hence the above hypothesis was proved to be valid. In this study it is believed that through a needs analysis survey, recreation service providers can determine the type of recreation services that need to be provided for the aged than using a cafeteria approach.

\subsubsection{Location of recreation facilities}

About $29 \%$ of the respondents preferred that a recreation facility should be in the most central place. At the same time, more than $50 \%$ indicated that a recreation facility should be located in a place that is accessible by different means of transport. Therefore it can be inferred that about $81 \%$ of the respondents, prefer the location of recreation facilities to be either at a central place or a place that is easily accessible by whatever mode of transport. This way of thinking happens to be consistent in almost all the local councils with the exception of the North Central Local Council. This line of reasoning happens to be in line with the recreation policy enshrined in the South African White Paper on Sports and Recreation (1998), which states that recreation participation is a fundamental right. All people of South Africa, irrespective of gender, age, race, language, culture, political persuasion, affiliation, disability or status should afford and access the offered recreation programmes and facilities.

The question of location has not been limited to responses that come from the different local councils. It was the intention of the study to further solicit information from all the respondents about their feeling in the following cases:

a Whether the aged population should be provided with recreation facilities; and

b The place within the local council that they think the recreation facilities for the aged should be located. 
About $87,7 \%$ of the respondents are agreeable to the provision of recreation facilities for the aged. Inferring from Table 7 below, it can be safely stated $8 \mathrm{I}$ percent of the respondents felt that the recreation facilities should be located at either the central or the most accessible place.

Table 7 Facilities provision as against location

\begin{tabular}{|c|c|c|c|c|c|c|c|c|c|c|c|c|}
\hline \multirow{3}{*}{$\begin{array}{l}\text { OPINIONS ON } \\
\text { FACILITIES } \\
\text { PROVISION } \\
\text { (RESPONSES) }\end{array}$} & \multicolumn{10}{|c|}{ OPINIONS ON FACILITIES LOCATION (RESPONSES) } & & \\
\hline & \multicolumn{2}{|c|}{ Central Place } & \multicolumn{2}{|c|}{ Accessible Place } & \multicolumn{2}{|c|}{ Local Town } & \multicolumn{2}{|c|}{ Walking Distance } & \multicolumn{2}{|c|}{ Do Not Know } & \multicolumn{2}{|c|}{ TOTAL } \\
\hline & $\mathbf{F}$ & $\%$ & $\mathbf{F}$ & $\%$ & $\mathbf{F}$ & $\%$ & $\mathbf{F}$ & $\%$ & $\mathbf{F}$ & $\%$ & $\mathbf{F}$ & $\%$ \\
\hline Yes & 63 & 27,6 & 126 & 55,3 & 06 & 2,6 & 30 & 13,2 & 03 & 01,3 & 228 & 100 \\
\hline No & 01 & 16,7 & 04 & 66,6 & 00 & 00 & 00 & 00 & 01 & 16,7 & 006 & 100 \\
\hline Do Not Know & 11 & 42,3 & 06 & 23,1 & 02 & 7,7 & 06 & 23,1 & 01 & 03,8 & 026 & 100 \\
\hline TOTAL & 75 & 29 & 136 & 52 & 08 & 03 & 36 & 14 & 05 & 02 & 260 & 100 \\
\hline
\end{tabular}

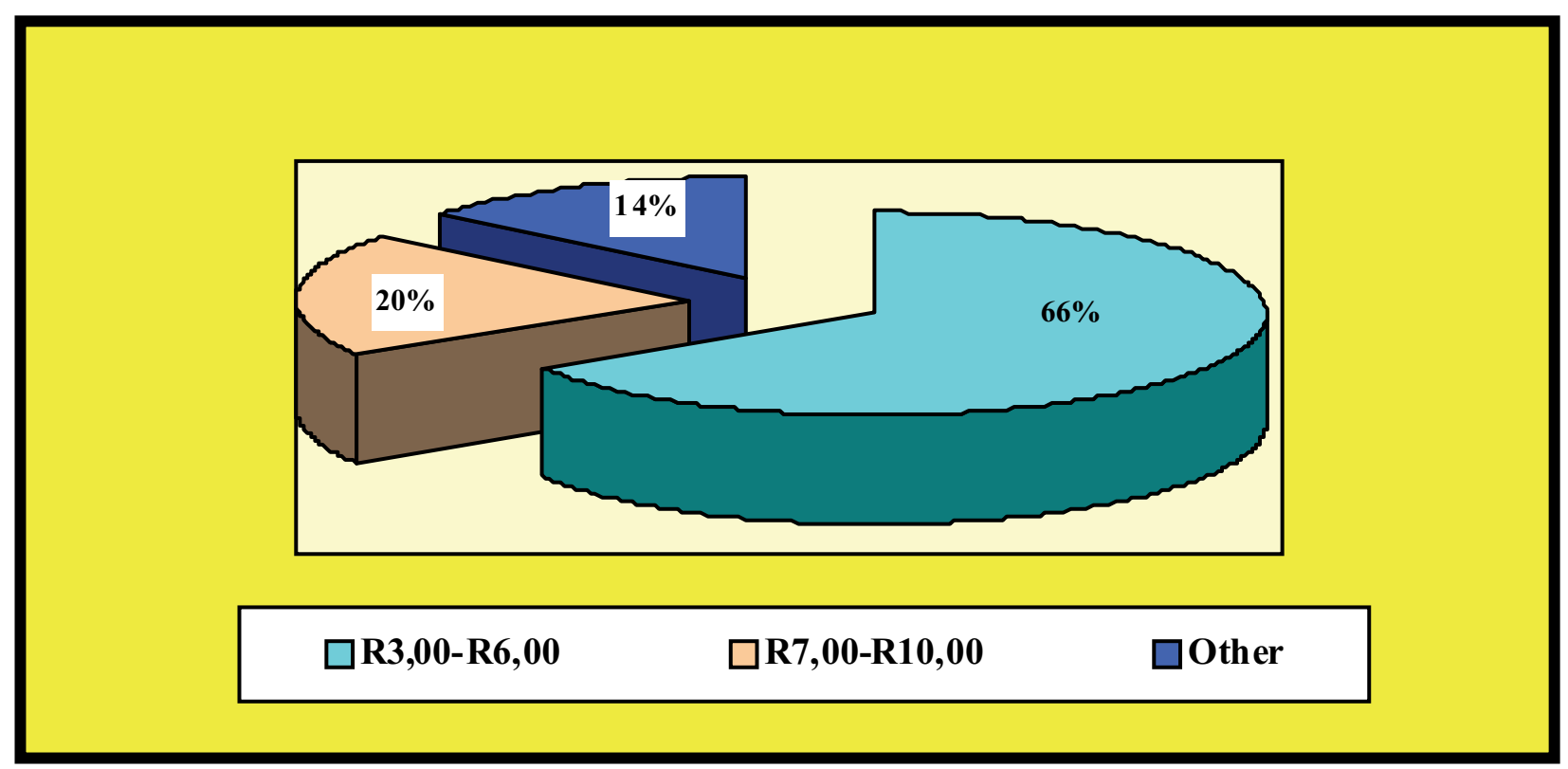

Figure 7 Transport fare the aged are prepared to pay

The location of recreation facilities and the minimum fare that the aged are prepared to pay have been seen by the researcher as two sides of the same coin. From Figure.7 it is noticeable that the majority $(66.2 \%)$ of the respondents (aged) only wants to be charged a return fare that ranges between R3, 00 and R6, 00 to access their recreation facilities. Only $33,8 \%$ of the respondents indicated that they feel that they need to be charged more than R6, 00. The reason why the aged prefer to pay far less than what the present economy demands, has been correctly summarised by Kaplan (1953) and Sul Tcha and Lobo (2003) in that economic problems among the senior citizens act as a constraint and a barrier in accessing some of the available recreation services.

\subsubsection{Benefits of Recreation Participation to the Aged}

The question of recreation benefits in the study was closely aligned to the hypothesis that reads:

Participation of the Durban Metropolitan Area's aged populace in recreation activities benefits them physically, emotionally, socially and educationally.

About $86,9 \%$ of the aged perceive recreation participation as benefiting them. The rest of the population, that is, $3, I$ and 10 percent, indicated that recreation does not benefit them or they do not know. 
Table 8 Perceived recreation benefits (aged)

\begin{tabular}{|c|c|c|c|c|c|c|c|c|c|c|}
\hline \multicolumn{11}{|c|}{ (A) PHYSICAL BENEFIT } \\
\hline \multirow{3}{*}{ RESPONDENTS } & \multicolumn{8}{|c|}{ RESPONSES } & & \\
\hline & \multicolumn{2}{|c|}{ Fully Agree } & \multicolumn{2}{|c|}{ Agree } & \multicolumn{2}{|c|}{ Disagree } & \multicolumn{2}{|c|}{ Fully Disagree } & \multicolumn{2}{|c|}{ TOTAL } \\
\hline & $\mathbf{F}$ & $\%$ & $\mathbf{F}$ & $\%$ & $\mathbf{F}$ & $\%$ & $\mathbf{F}$ & $\%$ & $\mathbf{F}$ & $\%$ \\
\hline Blacks & 89 & 60,9 & 49 & 33,6 & 03 & 2,1 & 05 & 3,4 & 146 & 100 \\
\hline Whites & 41 & 70,7 & 13 & 22,4 & 03 & 5,2 & 01 & $\mathrm{I}, 7$ & 058 & 100 \\
\hline Coloureds & 08 & 36,4 & 13 & 59,1 & 01 & 4,5 & 00 & 00 & 022 & 100 \\
\hline Indians & 22 & 64,7 & 09 & 26,5 & 01 & 2,9 & 02 & 5,9 & 034 & 100 \\
\hline TOTAL & 160 & 61,5 & 84 & 32,3 & 08 & 3,1 & 08 & 3,1 & 260 & 100 \\
\hline
\end{tabular}

(B) EMOTIONAL BENEFIT

\begin{tabular}{lllllllllll}
\hline RESPONDENTS & $\mathbf{F}$ & $\%$ & $\mathbf{F}$ & $\%$ & $\mathbf{F}$ & $\%$ & $\mathbf{F}$ & $\%$ & $\mathbf{F}$ & $\%$ \\
\hline Blacks & 75 & 51,3 & 66 & 45,2 & 02 & 1,4 & 03 & 2,1 & 146 & 100 \\
\hline Whites & 34 & 58,6 & 22 & 37,9 & 02 & 3,5 & 00 & 00 & 058 & 100 \\
\hline Coloureds & 11 & 50,0 & 10 & 45,5 & 01 & 4,5 & 00 & 00 & 022 & 100 \\
\hline Indians & 22 & 64,7 & 09 & 26,5 & 00 & 00 & 03 & 8,8 & 034 & 100 \\
\hline TOTAL & $\mathbf{1 4 2}$ & $\mathbf{5 4 , 6}$ & $\mathbf{1 0 7}$ & $\mathbf{4 1 , 2}$ & $\mathbf{0 5}$ & $\mathbf{1 , 9}$ & $\mathbf{0 6}$ & $\mathbf{2 , 3}$ & $\mathbf{2 6 0}$ & $\mathbf{1 0 0}$ \\
\hline & & & $\mathrm{X}^{2}=14.29$ & $\mathrm{df}=9$ & $\mathrm{p}>0,05$ & & &
\end{tabular}

(C) SOCIAL BENEFIT

\begin{tabular}{lllllllllll}
\hline RESPONDENTS & $\mathbf{F}$ & $\%$ & $\mathbf{F}$ & $\%$ & $\mathbf{F}$ & $\%$ & $\mathbf{F}$ & $\%$ & $\mathbf{F}$ & $\%$ \\
\hline Blacks & 82 & 56,1 & 59 & 40,4 & 02 & $\mathrm{I}, 4$ & 03 & 2,1 & 146 & 100 \\
\hline Whites & 35 & 60,4 & 22 & 37,9 & 01 & 1,7 & 00 & 00 & 058 & 100 \\
\hline Coloureds & 10 & 45,5 & 12 & 54,5 & 00 & 00 & 00 & 00 & 022 & 100 \\
\hline Indians & 23 & 67,6 & 09 & 26,5 & 00 & 00 & 02 & 5,9 & 034 & 100 \\
\hline TOTAL & $\mathbf{1 5 0}$ & $\mathbf{5 7 , 7}$ & $\mathbf{1 0 2}$ & $\mathbf{3 9 , 2}$ & $\mathbf{0 3}$ & $\mathbf{1 , 2}$ & $\mathbf{0 5}$ & $\mathbf{1 , 9}$ & $\mathbf{2 6 0}$ & $\mathbf{1 0 0}$ \\
\hline & & & & $\mathrm{X}^{2}=9.28 \quad$ df $=9$ & $\mathrm{p}>0,05$ & & &
\end{tabular}

\section{(D) EDUCATIONAL BENEFIT}

\begin{tabular}{lllllllllll}
\hline RESPONDENTS & $\mathbf{F}$ & $\%$ & $\mathbf{F}$ & $\%$ & $\mathbf{F}$ & $\%$ & $\mathbf{F}$ & $\%$ & $\mathbf{F}$ & $\%$ \\
\hline Blacks & 72 & 49,3 & 65 & 44,5 & 03 & 2,1 & 06 & 4,1 & 146 & 100 \\
\hline Whites & 35 & 60,4 & 22 & 37,9 & 01 & 1,7 & 00 & 00 & 058 & 100 \\
\hline Coloureds & 06 & 27,3 & 15 & 68,2 & 01 & 4,5 & 00 & 00 & 022 & 100 \\
\hline Indians & 22 & 64,7 & 10 & 29,5 & 01 & 2,9 & 01 & 2,9 & 034 & 100 \\
\hline TOTAL & $\mathbf{1 3 5}$ & $\mathbf{5 1 , 9}$ & $\mathbf{I I 2}$ & $\mathbf{4 3 , 1}$ & $\mathbf{0 6}$ & $\mathbf{2 , 3}$ & $\mathbf{0 7}$ & $\mathbf{2 , 7}$ & $\mathbf{2 6 0}$ & $\mathbf{1 0 0}$ \\
\hline & & $\mathrm{X}^{2}=13.66$ & $\mathrm{df}=9$ & $\mathrm{p}>0,05$ & & & &
\end{tabular}

4.4.6 Provision of recreation programmes for the aged

Another area of interest to the study was the provision of relevant recreation programmes for the aged. The hypothesis postulated under this area was that if the aged in the Durban Metropolitan Area can be exposed to recreation programmes, such exposure can improve their recreation participation. Respondents were subjected to a four point scale table that included the following:

$$
\text { Fully Agree (FA) }
$$

$$
\text { Agree (A) }
$$$$
\text { Disagree (DA) }
$$$$
\text { Fully Disagree (FDA) }
$$ 
93,8 Percent of the respondents agree that exposure to different recreation programmes coupled with recreation facilities provision, have a positive impact on aged recreation participation. Only 6.2 percent of the respondents do not think so. It is interesting to note that of the respondents from the various racial backgrounds, more than 90 percent share the same views about exposure to various activities as one form that can increase recreation participation of the aged.

\subsubsection{Provision of special concessions to participants}

Another viewpoint that this study solicited from the respondents related to the provision of special concessions by recreation service providers. The hypothesis that this section of the study has been addressing is that:

The recreation services providers must grant special concessions to the aged for the utilisation of their services.

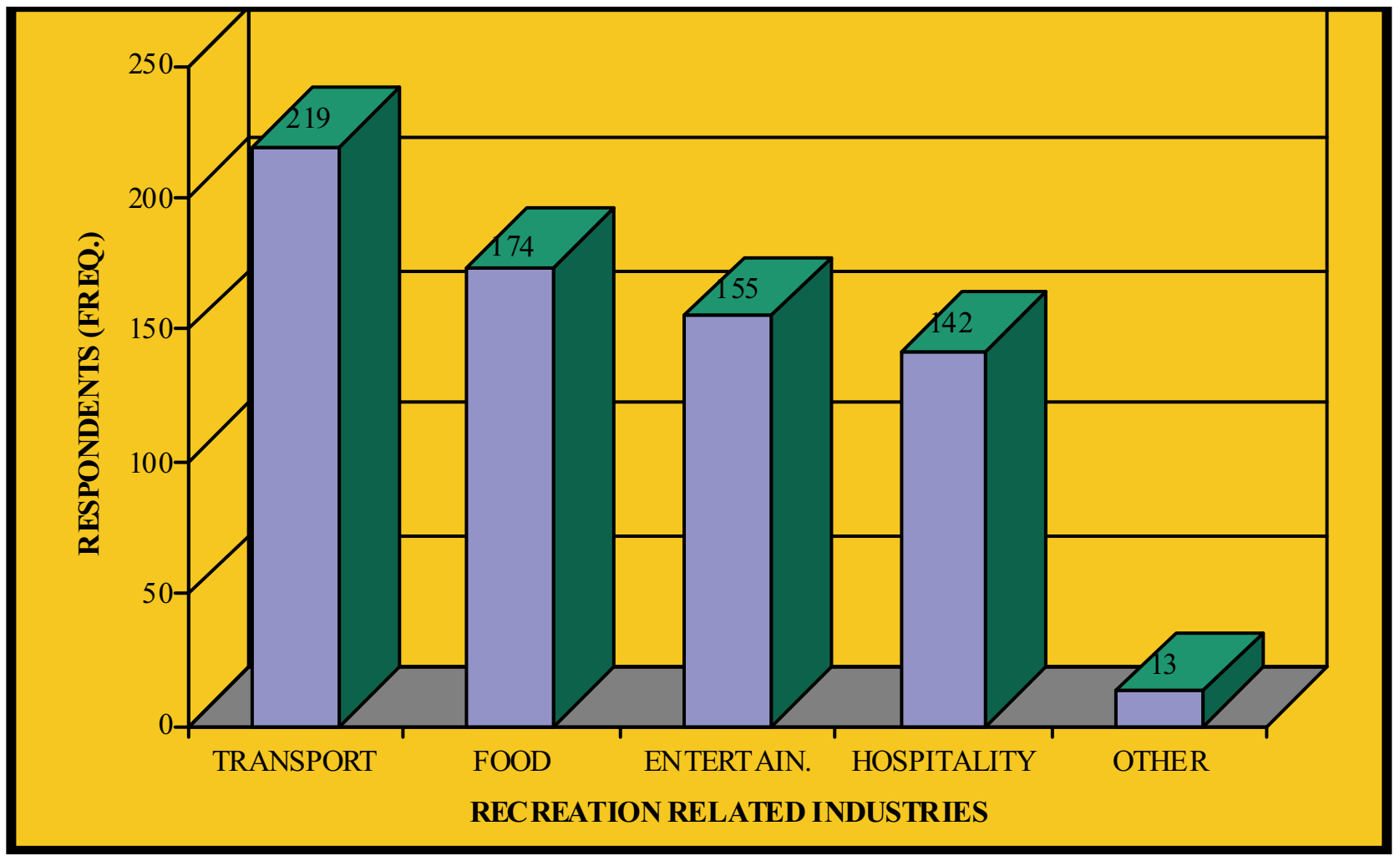

Figure 8 Recreation service providers to grant concessions [frequency]

It is believed that the transport industry is leading this list because many aged who are in the Durban Metropolitan Area feel that they are far away from places that offer recreation opportunities. One way, therefore, of accessing the recreation facilities is through the use of public transport.

4.5 Public perceptions on aged recreation

In order to avoid bias, the study also collected information from the unaffected parties who are the general public. The focus area in this section was the opinions of the general public with regard to recreation participation of the aged in the study area.

What can be inferred from Table $9(\mathrm{~A})$ is that $80 \%$ of the general public feel that the participation in recreation activities of the Blacks' aged living in the Durban Metropolitan Area is low. All the members of the public irrespective of the educational level share the same opinion. Only II\% think that the recreation participation is fairly high, while the remaining respondents, that is, about 9 percent, think that it is fair or rather within acceptable standards. 
Table 9 Public perceptions of the recreation participation of the aged $(n=100)$

\begin{tabular}{|c|c|c|c|c|c|c|c|c|c|c|c|c|}
\hline \multirow{3}{*}{ EDUCATION LEVEL } & \multicolumn{10}{|c|}{ (a) Responses (Blacks) } & \multicolumn{2}{|c|}{ TOTAL } \\
\hline & \multicolumn{2}{|c|}{ Very High } & \multicolumn{2}{|c|}{ High } & \multicolumn{2}{|c|}{ Fair } & \multicolumn{2}{|c|}{ Low } & \multicolumn{2}{|c|}{ Very Low } & \multirow[b]{2}{*}{$\mathbf{F}$} & \multirow[b]{2}{*}{$\%$} \\
\hline & $\mathbf{F}$ & $\%$ & $\mathbf{F}$ & $\%$ & $\mathbf{F}$ & $\%$ & $\mathbf{F}$ & $\%$ & $\mathbf{F}$ & $\%$ & & \\
\hline Junior Phase & 00 & 00 & 00 & 00 & 00 & 00 & 02 & 100 & 00 & 00 & 02 & 100 \\
\hline Intermediate Phase & 00 & 00 & 00 & 00 & 3 & 60 & 00 & 00 & 02 & 40 & 05 & 100 \\
\hline Senior Phase & 00 & 00 & 02 & 22 & 00 & 00 & 00 & 00 & 00 & 78 & 09 & 100 \\
\hline FET Phase & 04 & 44 & 00 & 00 & 00 & 00 & 00 & 00 & 05 & 56 & 09 & 100 \\
\hline Post Matric.Phase & 02 & 03 & 03 & 04 & 06 & 08 & 31 & 41 & 33 & 44 & 75 & 100 \\
\hline TOTAL & 06 & 06 & 05 & 05 & 09 & 09 & 33 & 33 & 47 & 47 & 100 & 100 \\
\hline SUMMARY & & & & & & & & & & & & \\
\hline \multirow{2}{*}{ EDUCATION LEVEL } & \multicolumn{10}{|c|}{ (b) Responses (Whites) } & \multicolumn{2}{|c|}{ TOTAL } \\
\hline & $\mathbf{F}$ & $\%$ & $\mathbf{F}$ & $\%$ & $\mathbf{F}$ & $\%$ & $\mathbf{F}$ & $\%$ & $\mathbf{F}$ & $\%$ & $\mathbf{F}$ & $\%$ \\
\hline Junior Phase & 02 & 100 & 00 & 00 & 00 & 00 & 00 & 00 & 00 & 00 & 02 & 100 \\
\hline Intermediate Phase & 02 & 40 & 02 & 40 & 00 & 00 & 00 & 00 & 01 & 20 & 05 & 100 \\
\hline Senior Phase & 07 & 78 & 02 & 22 & 00 & 00 & 00 & 00 & 00 & 00 & 09 & 100 \\
\hline FET Phase & 06 & 67 & 01 & 11 & 00 & 00 & 00 & 00 & 02 & 22 & 09 & 100 \\
\hline Post Matric.Phase & 39 & 52 & 27 & 36 & 04 & 05 & 03 & 04 & 02 & 03 & 75 & 100 \\
\hline TOTAL & 56 & 56 & 32 & 32 & 04 & 04 & 03 & 03 & 05 & 05 & 100 & 100 \\
\hline \multirow[t]{2}{*}{ SUMMARY } & \multirow{2}{*}{\multicolumn{3}{|c|}{88}} & \multicolumn{3}{|c|}{04} & \multicolumn{4}{|c|}{08} & \multicolumn{2}{|c|}{100} \\
\hline & & & & \multicolumn{4}{|c|}{ (c) Responses (Indians) } & & & & \multicolumn{2}{|c|}{ TOTAL } \\
\hline EDUCATION LEVEL & $\mathbf{F}$ & $\%$ & $\mathbf{F}$ & $\%$ & $\mathbf{F}$ & $\%$ & $\mathbf{F}$ & $\%$ & $\mathbf{F}$ & $\%$ & $\mathbf{F}$ & $\%$ \\
\hline Junior Phase & 00 & 00 & 02 & 00 & 00 & 00 & 00 & 00 & 00 & 00 & 02 & 100 \\
\hline Intermediate Phase & 00 & 00 & 00 & 00 & 04 & 80 & 00 & 00 & 01 & 20 & 05 & 100 \\
\hline Senior Phase & 00 & 00 & 05 & 56 & 04 & 44 & 00 & 00 & 00 & 00 & 09 & 100 \\
\hline FET Phase & 02 & 22 & 04 & 45 & 03 & 33 & 00 & 00 & 00 & 00 & 09 & 100 \\
\hline Post Matric.Phase & 06 & 08 & 22 & 29 & 23 & 31 & 22 & 29 & 02 & 03 & 75 & 100 \\
\hline TOTAL & 08 & 08 & 33 & 33 & 34 & 34 & 22 & 22 & 03 & 03 & 100 & 100 \\
\hline \multirow[t]{2}{*}{ SUMMARY } & \multicolumn{3}{|c|}{41} & \multicolumn{3}{|c|}{34} & \multicolumn{4}{|c|}{25} & & \\
\hline & & & & (d) $\mathrm{R}$ & oons & (Colc & reds) & & & & & AL \\
\hline EDUCATION LEVEL & $\mathbf{F}$ & $\%$ & $\mathbf{F}$ & $\%$ & $\mathbf{F}$ & $\%$ & $\mathbf{F}$ & $\%$ & $\mathbf{F}$ & $\%$ & $\mathbf{F}$ & $\%$ \\
\hline Junior Phase & 00 & 00 & 00 & 00 & 02 & 100 & 00 & 00 & 00 & 00 & 02 & 100 \\
\hline Intermediate Phase & 00 & 00 & 00 & 00 & 04 & 80 & 00 & 00 & 01 & 20 & 05 & 100 \\
\hline Senior Phase & 02 & 22 & 02 & 22 & 01 & 11 & 04 & 45 & 00 & 00 & 09 & 100 \\
\hline FET Phase & 02 & 22 & 00 & 00 & 02 & 22 & 05 & 56 & 00 & 00 & 09 & 100 \\
\hline Post Matric.Phase & 00 & 00 & 16 & 21 & 27 & 36 & 26 & 35 & 06 & 08 & 75 & 100 \\
\hline TOTAL & 04 & 04 & 18 & 18 & 36 & 36 & 35 & 35 & 07 & 07 & 100 & 100 \\
\hline SUMMARY & & & & & & & & & & & & \\
\hline
\end{tabular}

4.5. I Availability of recreation services in the study area

The general public has been requested in this study to air their views when it comes to the provision of both the recreation facilities and recreation programmes for the aged in the Durban Metropolitan Area. This was based on the 
following hypothesis:

That the aged population in the Durban Metropolitan Area is not adequately provided with recreation facilities.

$48 \%$ and $25 \%$, think that the facilities are inadequate or not available. Only $14 \%$ and $13 \%$ respectively think that the facilities are many or fairly sufficient.

Following the adequacy of recreation programmes, another hypothesis postulated in the study is:

That recreation participation of the aged living in the Durban Metropolitan Area can improve if relevant recreation programmes can be conducted.

Ninety five percent $(95 \%)$ of the respondents are of the opinion that the exposure of the aged population to recreation programmes will most likely improve their participation in recreation activities. Hundred percent $(100 \%)$ of both the Blacks and Indians strongly agree that this exposure will improve the participation of the aged in recreation activities. Only 17\% of both the White and the Coloured respondents do not agree that the exposure to recreation programmes will improve participation. Once more the significance of this hypothesis was subjected to the chi-square test. The results obtained of 0,000 shows that the level of significance is very high. A result of this nature suggests that a significant number of participants believe that there is a strong relationship between exposure to recreation programmes and recreation participation.

\subsubsection{Needs analysis survey in recreation provision}

The aged population in the Durban Metropolitan Area as the targeted population sample were requested to comment on the hypothesis that reads:

"There is a lack of a needs analysis when it comes to the provision of recreation facilities for the aged in the Durban Metropolitan Area"

In order to ascertain whether the public share the same perception with that of the aged, the researcher decided to pose the same question to the general public.

About $92 \%$ of the respondents are of the opinion that there is a lack of a needs analysis survey when it comes to the provision of recreation facilities for the aged in the Durban Metropolitan Area. It is interesting to note that that 100 percent of the respondents from both the Indian and the White communities that were interviewed also share the same sentiments. The 5 percent who disagrees to this is made up of both the Blacks and the Coloureds.

\subsubsection{Perception on recreation values}

The respondents were requested to give their opinions in areas where they think the aged are benefiting from recreation participation. Soliciting the views of the public about the values of recreation was based on the hypothesis that reads:

"That the aged in the Durban Metropolitan Area who are participating in recreation activities value their participation".

About 100 percent of the respondents from the White population group think of recreation participation as benefiting the aged population. A result of this nature might be caused by the exposure of the Whites to various recreation activities. Only 3 percent of the respondents from the Black population group are of the opinion that the participation of the aged in recreation activities does not benefit them.

Another area of concern that relates to recreation participation in the study has been that of benefit. This study wanted to establish the exact areas where recreation participation is seen to be benefiting the aged. The appropriateness of such an investigation was in line with the research hypothesis that reads:

"That participation of the Durban Metropolitan Area's aged populace in recreation activities benefits them physically, emotionally, socially and educationally".

An average of 97 percent of the respondents is of the opinion that recreation participation benefits the aged physically, emotionally, socially and educationally. It is interesting to note that from both the White and Coloured respondents 100 percent of the respondents are of the same opinion. Both the Blacks and the Indians share the 3 percent of the respondents that do not perceive recreation participation as benefiting the aged. The hypothesis that reads that:

Participation of the Durban Metropolitan Area's aged populace in recreation activities benefits them physically,

emotionally, socially and educationally is thus proved to be valid.

\subsubsection{Location of recreation facilities}

The order of preference as viewed by the general public when it comes to the location of a recreation facility, is accessible place (53\%); central place (27\%); within walking distance (18\%); and local town (02\%).

The importance of the location of a recreation facility is important especially in dealing with the aged population. Torkildsen (2001:247) in re-emphasising the question of location says: 
Ideally, a public leisure facility should be located on or near a main road that is well served by a public transport system, in close proximity to other leisure facilities, with good direct access to and off the site. In this way the accessibility of the facility is improved and the catchment area is extended along the main road. The main road will ensure that the people travelling along the route will have a high level of awareness of the facility, and this can be exploited in terms of promotion.

\subsubsection{Concessions in recreation services utilisation}

In considering the question of the supplier and the consumer, the researcher found it proper to request the opinions of the general public when it comes to granting concessions by recreation service suppliers. About 90 percent of the respondents are of the opinion that the aged should be granted special concessions in utilising the recreation services. The racial group which feel strongly about granting the aged special concessions are Blacks (97\%), followed by Indians $(91 \%)$ and thereafter Coloured $(83 \%)$ and Whites $(66 \%)$. Only 9 percent of the total number of respondents thinks that these special concessions should not be granted to the aged.

\section{Interpretation of data}

The construction of both the hypotheses and objectives underpinning this study has so far centred around four areas of investigation. The areas are:

- Recreation participation;

- Recreation provision;

- Recreation demand; and

- Recreation concessions.

\subsection{Recreation participation}

Recreation participation of the aged is therefore seen to be vital to the aged population's quality of life. Taking into consideration that the aged are faced with multi-faceted problems related to their well-being, the majority of the respondents in the study indirectly indicated that physical fitness activities are needed as they are likely to help in facilitating an active, dynamic, and healthy quality of life. More than 80 percent of the aged and more than 95 percent of the public indicated that recreation participation of the aged benefit the aged. The hypothesis that reads:

participation of the Durban Metropolitan Area's aged populace in recreation activities benefits them physically, emotionally, socially and educationally was proved to be valid.

\subsection{Recreation provision}

Considering that the provision of recreation facilities is one of the services, facilities must therefore be located in both accessible and central places for the aged. In short it seems that the majority of the respondents (aged and public) prefer either a central area or easily accessible area when it comes to the question of location of recreation facilities.

\subsection{Recreation demand}

The Durban Metropolitan Area being an area that has been subjected to two major political eras, that is, the era of apartheid that mainly benefited the Whites, and the democratic era that intends to benefit everybody, has a task of correcting the imbalances of the past through conducting a needs analysis survey when it comes to recreation provision. The respondents from both the aged and the public have indicated that there is a lack of a needs analysis survey in aged recreation services provision, and this also seems to be evident in all the local councils that make up the Durban Metropolitan Area.

\subsection{Recreation concessions}

The majority of the respondents, that is, 91 percent, think that the aged should be granted special concessions in utilising recreation resources. This shows that even the general public is aware of the financial limitations that the aged are confronted with. The opinion that is shared by the general public is that participation by the aged in some recreation activities is dependent on financial affordability or alternatively, the aged must be met half way in encouraging them to participate in recreation-related activities.

\subsection{Integrative discussion}

The findings that have been arrived at so far in this chapter suggest that recreation service providers need to follow certain guidelines in the provision of recreation services for the aged. The guidelines need to take into consideration all the findings that have been arrived at with respect to recreation participation, demand, provision and concessions. 


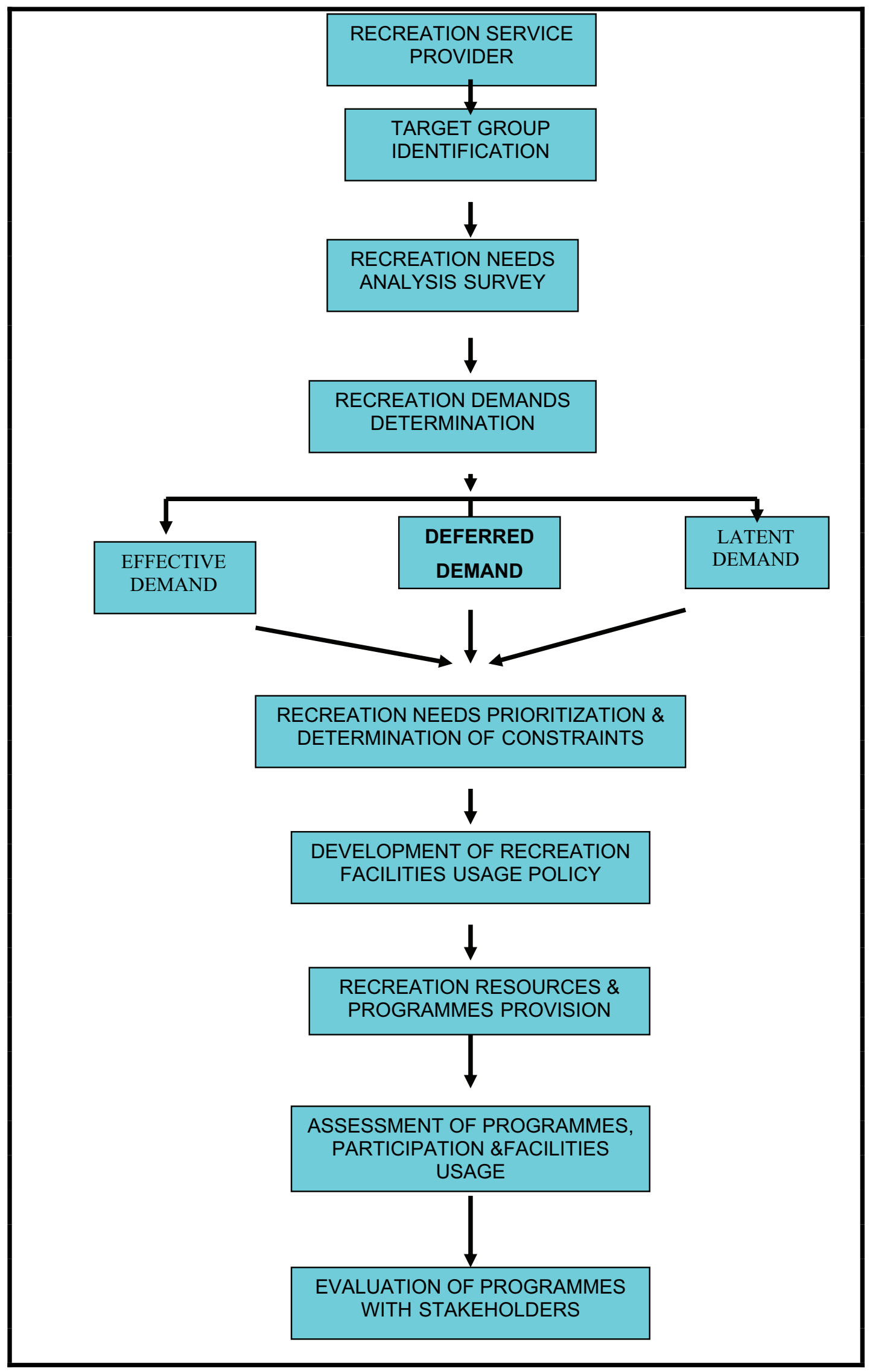

Figure 9 Recreation service provider's supply model 
Figure 9 is a schematic model of how recreation service providers in a multi-cultural area like the Durban Metropolitan Area should go about in providing the recreation services for any targeted population group.

From Figure 9 it is clear that having identified the group for which the recreation services have to be provided for, a needs analysis survey as suggested by the Boston Metropolitan Area Planning Council (1978-79) should be undertaken. From the needs analysis survey a service provider may be in a position to determine the different types of demand (effective demand, deferred demand and latent demand) that are required. A recreation service provider may from the different types of demand be in a position to determine recreation facilities that are urgently needed, as well as determine the constraints.

The model further suggests that prior to putting in place the required recreation facilities as inferred from the demand, policies governing the usage of facilities / services need to be established. It emanated from the findings that the question of concessions and location manifested itself as one of the constraints in the aged utilising the available recreation services.

Furthermore the required recreation programmes must accompany the usage of facilities in order to ensure their maximum utilisation. Having conducted the recreation programmes coupled with the utilisation of facilities, the model also suggests that a service provider must constantly assess the utilisation of facilities and the provided programmes. Thereafter a service provider must constantly evaluate the usage of facilities and programmes in order to determine whether the community are still benefiting from participation and the programmes offered.

The researcher believes that if service providers could use a model of this nature, this is likely to remove the problems of providing recreation facilities that are thought to be needed by people, rather than those that are actually needed by people. Furthermore the provision of facilities that are actually needed by people can also guarantee the maximum participation of people.

\section{Recommendations}

This study revealed some issues that warrant attention by those responsible for aged recreation services. Consequently, some actions need to be undertaken. The main issues raised in the study revolve around the operational hypotheses and objectives of the study. This includes recreation participation, recreation provision, recreation demand and recreation concessions. All of these main issues are focussed on the targeted population that is the aged.

6.1 Recreation participation of the aged

The findings relating to the theme of recreation participation have shown that the aged participation in recreation activities within the Durban Metropolitan Area is rather limited. The limitations of participation of the aged in recreation activities tend to be common among the previously disadvantaged population groups. For the participation of the aged to improve in recreation activities, it is recommended that this group be exposed to multi-faceted recreation activities.

In exposing the aged, especially those belonging to the historically disadvantaged group, recreation programmes for the aged need to be introduced. The introduction of these recreation programmes is seen primarily to be the function that can be performed by both the public and private sector. The recreation programmes designed for the aged need to be deployed in all the local councils found within the Durban Metropolitan Area. Both the public and private sector need to ensure that professionals in the field conduct these programmes.

What has also been deduced from this study is that the aged within the Durban Metropolitan Area are aware of the benefits of recreation participation. The message that recreation participation benefits the aged can further be spread through the use of media. Local television and radio stations must be encouraged by the government to feature programmes aimed at making the aged aware of active recreation participation benefits.

Furthermore, the local newspapers need to feature a special section that is aimed at making the aged aware of active recreation participation benefits. This is likely to improve the participation of the aged in active recreation activities.

\subsection{Recreation services provision for the aged}

Exposing the aged to different recreation programmes can be a futile exercise if these are not accompanied by the provision of recreation services. What has come clear in this study is that the aged in the Durban Metropolitan Area are inadequately provided with recreation services.

It is therefore recommended that a needs analysis survey aimed at what can be provided for the aged in the Durban Metropolitan Area be conducted. A needs analysis survey of this nature can be conducted by the Recreation and Parks section within the municipality. The implementation of a needs analysis survey results is one way of ensuring that the recreation service providers are distributing the required recreation facilities for the aged. The problem of being aged is not a once off problem but is a problem that everyone is going to face at some time. Consequently, the provision of recreation services for the aged has a potential of benefiting everyone in the long run.

Inkanyiso, Jnl Hum \& Soc Sci 20I I, 2(2) 


\subsection{Recreation concessions}

It is understood that the majority of the aged has financial limitations. These financial limitations act as a barrier in making them to access recreation services. In addressing this problem of financial limitations of the aged the recreation service providers need to meet them half way. It is recommended that the government put in place a policy towards granting the aged concessions. A policy of this nature need to prescribe to the recreation service providers a percentage that need to be granted to the aged when they want to utilise recreation facilities. At the moment it appears that it is at the discretion of a recreation service provider to grant concessions. Some recreation service providers grant concessions while others do not. A policy of this nature will help the aged to know what they are entitled to and what they are not entitled to.

\section{Conclusion}

As this study is most concerned about provision of recreation services in an area that is undergoing drastic transformation, it will be appropriate to conclude by a quotation from Grey (1984) in Edginton et al. (2001:181)

This is a time of great concern, uncertainty, ambivalence, and ambiguity in the recreation and park movement. It is a time of change. Change brings crisis and opportunity. In periods of rapid change, reforms are possible that could never be accomplished in periods of stability. Flexibility, recognition of opportunity, escape from pessimistic thinking, and leadership are required to respond to this period.

\section{References}

Boston Metropolitan Area Planning Council (1978-79): Assessing recreation demand. Boston: MAPC.

Bucher, A. C., (1983): Foundations of physical education and sport. London. C. V. Mosby Co.

Carlson, R. E., Maclean, J. R., Deppe, T. R., and Peterson, J. A. (1979): Recreation and leisure: The changing scene. Belmont: Wadsworth Publishing Company.

Carpenter, G. (2003): Leisure and life perceptions of a mid-life woman experiencing the epiphany associated with leisure and family. World Leisure Journal: Vol. 45, No. 4: 44-54.

Eckstein, M. A. and Noah, H. J. (1973): Metropolitanism and education: Teachers and schools in Amsterdam, London, Paris and New York. The Institute of Philosophy and Politics of Education, Teachers College, Columbia University, 1973: I-3.

Edginton, C.R., Jordan, J.D., DeGraaf, G.D.,and Edginton, R.S. (200I): Leisure and life satisfaction: Foundational perspectives with power web. Boston: McGraw-Hill.

Fisher, K. J., Pickering, M. A., and Li, F. (2002): Healthy aging through active leisure: Design and methods of shape- a randomised controlled trial of a neighbourhood-based walking. World Leisure Journal, Vol. 44 No. I: 19-28.

Harahousou, Y., and Kabitsis, C. (2002): European models of leisure policies and physical activity programs for elderly people. World Leisure Journal, Vol. 44 No. I: 03-10.

Kaplan, J. (1953): A social program for older people. Minneapolis: The University of Minnesota Press.

Kraus, R (200I): Recreation and leisure in modern society. Tall Pine Drive: Jones and Bartlett Publishers.

Magi, LM. (1 188): What the Concept “Recreation" Means to Blacks. Publication Series of the University of Zululand. B. No. 74.

Magi, L.M., (1998): Statistical techniques and field research in geography. Unpublished manuscript. Centre for Recreation and Tourism. KwaDlangezwa: University of Zululand

Murphy, J. F. (198I): Concepts of Leisure. Englewood Cliffs N .J. Prentice Hall.

Nakhooda, J. (1961): Leisure and recreation in society. Kitab Mahal: Allahabad.

Ngcobo, N. R. (1998): The provision of recreation facilities for the youth in Umlazi township: A socio-spatial perspective. Unpublished MRT Dissertation, Durban-Umlazi Campus. University of Zululand

Oldman A (1996): Ageing well Europe - A model of health promotion for and with older people. Paper presented at the $4^{\text {th }}$ International Congress of physical activity, aging and sports, Heidelberg, Germany. August 27-3I.

Smith, D. H. and Theberge, N. (1987): Why people recreate. Champaign: Life Enhancement Publications.

South Africa White Paper on Sport and Recreation (1995): National Department of Sport and Recreation. Pretoria: South African Government printers.

Sul Tcha, S., and Lobo, F. (2003): Analysis of constraints to sport and leisure participation: The case of Korean immigrants in Western Australia. World Leisure Journal, Vol. 45 No.3: 13-23.

Torkildsen, G. (200I): Leisure and recreation management. London: E \& F. N. Spon.

Weiskopf, D. C. (1978): A guide to recreation and leisure. Boston: Allyn and Bacon Inc. 